\title{
Interstate Marketing of Indian Water Rights: The Impact of the Commerce Clause
}

\author{
Chris Seldin $\dagger$
}

In recent years, Native American Indian tribes and Indian law commentators have increasingly advocated off-reservation uses of Indian water rights. They note that, for many tribes, marketing tribal water offreservation can generate substantial revenue from a resource for which the tribes have little present use on the reservation. Finding off-reservation markets, however, will often require leasing water to users in other states, and many states have laws that would prohibit or substantially impede such interstate leases. After concluding that the dormant Interstate Commerce Clause may leave states with some ability to inhibit interstate leases of water rights in general, the author examines whether Indian sovereignty doctrine requires treating Indian water rights differently. In general, states may not regulate the on-reservation activities of Indian tribes. States might attempt, however, to inhibit interstate Indian water marketing by either regulating the non-Indian party to a water marketing transaction, or by attempting to characterize an interstate lease as a wholly offreservation activity. The author argues that a principled reading of the Supreme Court's sovereignty jurisprudence would preclude states from regulating interstate Indian water marketing even through these "back doors."

\section{INTRODUCTION}

In recent years, an increasing number of commentators have advocated allowing Native American Indian tribes ${ }^{1}$ to sell or lease their

Copyright $\odot 1999$ Chris Seldin and California Law Review, Inc.

$\dagger$ B.A., Dartmouth College, 1993; J.D., School of Law, University of California, Berkeley (Boalt Hall), 1999. The author wishes to thank a number of people who graciously gave of their time and expertise. First, the author expresses his deep gratitude to Joe Sax for advising him on this project from start to finish, and for countless challenging conversations on the law and politics of the west. David Getches also provided valuable insight and advice near the inception of the project, and a trenchant review of the manuscript at a later stage. Greg Hobbs both critically reviewed the manuscript and offered valuable counterpoints regarding the piece's content. Finally, Lori Potter's contributions to the author's work, both in this piece and elsewhere, are too numerous to do justice in a footnote. 
indigenous water rights. ${ }^{2}$ These advocates maintain that allowing tribes to sell or lease their water can generate revenues for tribes from a resource for which many tribes have little present use on the reservations, and facilitate recognition of tribal water rights without disrupting the system of nonIndian water rights on streams. ${ }^{3}$ Indeed, for many tribes, unused water rights constitute one of their most valuable potential sources of revenue. A number of tribes have indicated their eagerness to explore this use of their water rights, ${ }^{4}$ and this Comment assumes that, in general, allowing Indian tribes to market ${ }^{5}$ their water, either intra- or interstate, is good public policy.

For reasons of geography, however, achieving an active market in Indian water rights will often require marketing tribal water across state lines. This raises a potential obstacle to the tribes' ability to market their water: restraints on interstate water marketing imposed by state law. ${ }^{6}$ This Comment explores the question of whether states may validly restrict interstate Indian water marketing transactions. ${ }^{7}$

1. Following the convention in this area of law, I refer to Native American rights as "Indian" rights.

2. See, e.g., David H. Getches, Management and Marketing of Indian Water: From Conflict to Pragmatism, 58 U. Colo. L. REv. 515, 54 1-48 (1988); Karen M. Schapiro, An Argutuent for the Marketability of Indian Reserved Water Rights: Tapping the Untapped Reservoir, 23 IDAHO L. REv. 277 (1987); Christine Lichtenfels, Comment, Indian Reserved Water Rights: An Argument for the Right to Export and Sell, 24 LAND \& WATER L. REV. 131 (1989); Sylvia F. Liu, Comment, American Indian Reserved Water Rights: The Federal Obligation to Protect Tribal Water Resources and Tribal Autonomy, 25 EnvTl. L. 425 (1995); Lee Herold Storey, Comment, Leasing Indian Water Off the Reservation: A Use Consistent with the Reservation's Purpose, 76 CALIF. L. REv. 179, 206-18 (1988).

Others, of course, counter that neither Congress nor the Court ever intended to award Indian tribes with more water than they actually need on their reservations, and that allowing tribes to scll unused entitlements would therefore run counter to the purpose of the tribal right. See, e.g., Jack D. Palma II, Considerations and Conclusions Conceming the Transferability of Indian Water Rights, 20 NAT. ResouRCES J.91 (1980).

3. See Getches, supra note 2, at 543-44; Schapiro, supra note 2, at 291; Lichtenfels, supra note 2, at 146; Storey, supra note 2, at 216.

4. See Position Paper of the Ten Indian Tribes with Water Rights in the Colorado River Basin Submitted to the Seven States in the Colorado River Basin (on file with the author); see also 63 Fed. Reg. 51,367, 51,367 (1998) (requesting comment on Chemehuevi Tribe's proposal to market watcr within the state of California); 61 Fed. Reg. 53,756, 53,756-57 (1996) (announcing Ak-Chin Tribe's request to market water within the state of Arizona).

5. My use of the term "market" is intended to subsume all mechanisms enabling a transfer of water or water rights, including traditional market mechanisms such as sales or leases as well as more flexible solutions like water banking. For various reasons, however, the transaction contemplated here will in most if not all instances be a long-term lease.

6. Existing precedent suggests that tribes are likely immune from state intcrference with regard to water leases undertaken fully within reservation boundaries. See, e.g., Colville Confederated Tribes v. Walton, 647 F.2d 42, 52-53 (9th Cir. 1981). Because this Comment addresses interstate marketing of tribal water, it deals in nearly all cases with marketing outside of reservation boundaries. The law here is unclear.

7. This Comment does not examine whether or not federal law may bar interstate Indian watcr marketing. Several commentators contend that the Non-Intcrcourse Act, 25 U.S.C. $\$ 177$ (1999), which bars alienation of Indian land without congressional consent, applies to transfcrs of Indian water as 
The Comment moves in three stages. First, it briefly describes the differences between state-based water rights and Indian water rights, and argues that these differences create an expectation that Indian water rights should be free from state control. Second, it explores the controversial subject of whether the interstate Commerce Clause might constrain states from prohibiting water marketing across state lines. Included in this discussion of the dormant Interstate Commerce Clause is a look at how interstate compacts apportioning various rivers might affect the analysis. After concluding that states may retain some ability to inhibit interstate water 1narketing under the dormant Interstate Commerce Clause, the Comment inoves to its third and final stage: assessing whether Indian tribes should be treated differently pursuant to the Indian Commerce Clause and related sovereignty doctrine. The Comment concludes that, although states might attempt to block interstate Indian water marketing by regulating nonIndian parties to inarketing transactions on the one hand, or by characterizing a marketing transaction as occurring off-reservation on the other, a principled reading of the Supreme Court's contemporary Indian Commerce Clause and sovereignty jurisprudence would preclude states from barring interstate Indian water marketing transactions even through these approaches.

I

\section{INDIAN WATER RIGHTS}

\section{A. A Preferred Doctrine}

Indian water rights enjoy special status in the western water world. This special status, stemming from the unique features of Indian water rights discussed below, creates an expectation that constraints imposed on interstate marketing of ordinary water rights might not apply to Indian rights.

Ordinary "appropriative"8 water rights granted pursuant to state law base their claim to water on the date and amount of water first put to beneficial use. ${ }^{9}$ These rights must be used consistently to avoid forfeiture. ${ }^{10}$

well. See, e.g., Storey, supra note 2 , at $220 \mathrm{n} .18$. If they are correct, then the inquiry regarding state restraints on interstate Indian water marketing would turn on preemption. If Congress (or any agency acting with delegated powers) authorized off-reservation water marketing, the states would have to establish that their restraints did not conflict with the federal purpose embodied in the statute or regulation authorizing marketing. See infra note 176. This Comment, however, assumes that the Non-Intercourse Act is limited by its statutory language to transfers of land and does not apply to transfers of Indian water rights.

8. Some western states, notably California, still retain some elements of the riparian water doctrine derived from English common law. See A. DAN TARLock ET AL., Water Resource MANAGEMENT 241-43 (1993). Most, however, follow a pure appropriation system, and even those states honoring riparian rights recognize appropriative rights as well. See id. at 3 .

9. I do not undertake to explicate here all the basics of ordinary appropriative and riparian water rights. For a succinct and widely admired summary, see generally DAvid H. GETCHES, WATER LAW IN 
Moreover, once an appropriator uses her water right in a particular way, she cannot use the right in a different way or place if doing so would injure any other appropriator on the stream. ${ }^{11}$ And the authority for the water right itself comes from the state: The state grants a usufructuary right, but holds actual ownership of waters in public trust. ${ }^{12}$

Indian water rights, on the other hand, are creatures of federal law. ${ }^{13}$ They date their priority to at least the establishment of the reservation, ${ }^{14}$ and peg their quantification most typically to the "practicably irrigable acreage" on the reservation." They are known as "reserved rights," because they are deemed an essential part of the tribe's reservation, and apply to all streams that are in some way connected with the reservation. ${ }^{16}$ Importantly, reserved rights are not lost by non-use, ${ }^{17}$ and, in at least one way, are not subject to the "no-injury" rule described above. ${ }^{18}$ There is no question that the reserved water right does not come from the state. ${ }^{19}$

A NutShell (1997). For a more detailed exposition in treatise form, see A. DaN TARLock, LAW of
WATER RightS AND Resources (1988).
10. See TARLOCK, supra note 9, at 5-108.
11. See id. at 5-67.
12. See, e.g. , Colo. CoNST. art. XVI, $\$ 5$ (deelaring waters of streams public property); National Audubon Soc'y v. Superior Court, 658 P.2d 709, 718-29 (Cal. 1983) (holding waters of California subject to public trust doctrine).

13. See Winters v. United States, 207 U.S. 564, 577 (1908).

14. See id.; see also infra note 19.

15. Arizona v. California, 373 U.S. 546, 600 (1963).

16. This connection is usually physical-i.e., tribes have rights to surface water that is appurtenant to their reservations. But in Arizona v. California, the Supreme Court awarded water to the Cocopah Tribe from the Colorado River system even though their reservation did not physically touch the system, because the Tribe was found to have relied on that source of water in the past. See id. at 596.

17. See id. at 600 .

18. Because reserved rights need not be used to retain their validity, they are essentially a dormant "use" until exercised. This change from dormant use to active use, of course, does not trigger the no-injury rule. Were the rule otherwise, many tribes could never begin using their water rights. Many commentators have argued with some foree, however, that the no-injury rule ought to apply to tribes attempting to change the use of a water right from one active use to another. See, e.g., Storey, supra note 2 , at 212 .

19. In fact, there is also an argument that, at least under Winters, the reserved right did not come from the federal government either. Instead, the water right simply remained with the tribe when it ceded the remainder of its lands to the federal government. See Winters, 207 U.S. at 576. A close reading of Winters suggests that the Court felt that the tribe in that case had not ceded its waters to the federal government in its treaty with the U.S. Accordingly, the water stayed with the tribes, and was never the federal government's to reserve for them. Note, however, that this interpretation of Winters leads to trouble for reservations that are not ancestral tribal territory, and possibly for tribes created by Executive Order. The more consistent conception of reserved rights, therefore, does view the reserved right as something set aside by the federal government as of the date of the establishment of the reservation. It is this view that the Court adopted in Arizona v. California. See 373 U.S. at 600 . 
There is one exception to this differential, privileged treatment of Indian water rights, but it appears to be the exception that proves the rule. ${ }^{20}$ The McCarran Amendment, ${ }^{21}$ as construed by the Supreme Court in Colorado River Water Conservation District v. United States, ${ }^{22}$ gives state courts the power to adjudicate Indian water rights in the process of performing a comprehensive stream-wide adjudication. ${ }^{23}$ Even here, however, the inroads on Indian water rights' privileged position are limited. Importantly, when state courts do adjudicate Indian water rights, federal law governs the state court's prioritization and quantification of Indian water rights, not state law. ${ }^{24}$ In its operation, therefore, even the McCarran Amendment implicitly recognizes that Indian water rights require different treatnient from state rights, and are not to be subjected to state law.

Perhaps the most important lesson to be drawn from the McCarran Amendment lies in the fact that Congress had to act affirmatively there to subject Indian water rights to any state control at all. Absent such an affirmative congressional act, therefore, it appears that Indian water rights are by default free of state control. ${ }^{25}$

20. See GeTches, supra note 8, at 342 ("The only significant area of state jurisdiction Congress has allowed over Indian water rights is the McCarran Amendment's authority to adjudicate Indian water rights in state proceedings.").

21. 43 U.S.C. $\$ 666$ (1998).

22. 424 U.S. 800 (1976). The Court expanded the holding in Colorado River, which was geographically limited in scope, to cover the entire west in Arizona v. San Carlos Apache Tribe of Arizona, 463 U.S. 545, 561-65 (1983).

23. At least two commentators have contended that the legislative history of the McCarran Amendinent indicates that Congress never intended for it to apply to Indian water rights. See Scott B. McElroy \& Jeff J. Davis, Revisiting Colorado River Water Conservation District v. United StatesThere Must Be a Better Way, 27 ARIz. ST. L.J. 597, 601-05 (1995).

24. See San Carlos Apache, 463 U.S. at 571. This aspect of the decision in San Carlos Apache makes clear that the joinder of Indian reserved water rights in general adjudications should not be read as creating a more general loophole allowing states to assert authority over Indian water rights. Indeed, as the Court noted there, "Nothing we say today should be understood to represent even the slightest retreat from the general proposition we expressed so recently in New Mexico v. Mescalero Apache Tribe, 462 U.S. 324, 332 (1983): 'Because of their sovereign status, [Indian] tribes and their reservation lands are insulated in some respects by an historic immunity from state and local control, and tribes retain any aspect of their historical sovereignty not inconsistent with the overriding interests of the National Government." Id. at 570-71 (internal punctuation and citation omitted). For further discussion of New Mexico v. Mescalero Apache Tribe, see infra notes 112-18 and accompanying text.

25. This position is strengthened by language in Public Law 280 excepting state jurisdiction over "alienation, encuunbrance, or taxation of . . . water rights . . . belonging to any Indian tribe." 25 U.S.C $\$$ 1322(b) (1998); 28 U.S.C. $\$ 1360$ (b) (1998). For further discussion of Public Law 280, see infra notes 155-58 and accompanying text.

It is also true, of course, that the Supreme Court might interpret Indian water rights as inherentiy subject to state control in one or inore ways. As creatures of federal case law, Indian water rights are presumably open to "clarification" at the hands of the Court. See infra note 38 (discussing a recent draft Supreme Court opinion that would have altered some aspects of Indian water rights doctrine). Under current law, however, it seems fair to characterize the weight of authority as establishing a general expectation of freedom from state control. 


\section{B. Doctrinal Differences and Real-World Conflicts}

The special rules governing Indian water rights have tremendous consequences for western streams and the non-Indian communities that depend on them. Because many reservations were established before nonIndians began appropriating water from affected streams, tribal reserved rights are superior to many if not most state appropriative rights. But due to lagging development of tribal water rights, ${ }^{26}$ in most cases non-Indian uses based on state law were established on streams well before tribes were able to make use of water to which they were entitled. ${ }^{27}$ In many cases, tribes still have not put to use water rights to which they have been entitled for decades. ${ }^{28}$ This, of course, creates a potential for substantial conflict between tribes and existing state-law users, because an exercise of tribal water rights could in many cases displace existing non-Indian uses.

Moreover, the magnitude of Indian water rights under prevailing quantification doctrine ${ }^{29}$ assures that the preemptive potential of Indian water rights discussed above could have wide-reaching consequences on affected stream systems. The prevailing standard, announced by the Court in Arizona v. California, ${ }^{30}$ awards tribes water rights based on the amount of acreage withm their reservation that is "practicably irrigable."31 Determining the amount of irrigable land under this "practicably irrigable acreage" ("PIA") standard involves technical procedures requiring engineering and soils evaluations. ${ }^{32}$ The standard has resulted in tremendous awards of water to some tribes. In Arizona v. California, for example, the five affected tribes received roughly $1,000,000$ acre feet of water ${ }^{33}$ This

26. Many blame the federal and state governments for the disparate development trajectories that have clearly worked to the disadvantage of the tribes. See, e.g., National WATER Commission, Water Policies for the Future-Final Report to the President and to the Congress of the UNITED STATES 475 (1973) ("In the history of the United States Government's treatment of Indian tribes, its failure to protect Indian water rights for use on the Reservations it set aside for them is one of the sorrier chapters."); Western Water POLICY RevieW Advisory Commission, Water IN the West: Challenge for the Next Century 6-9 (1998) ("The federal government should recognize that it has often failed to protect prior and paramount Indian water rights while encouraging and finaneing non-Indian water development."); Stephen M. Feldman, The Supreme Court's New Sovereign Immunity Doctrine and the McCarran Amendment: Toward Ending State Adjudication of Indian Water Rights, 18 Harv. ENvtl. L. Rev. 433, 444-53 (1994); Peter Torren, Comment, The Adjudication of Indian Water Rights in State Courts, 19 U.S.F. L. REv. 27 (1984).

27. See Getches, supra note 2, at 516-17.

28. See Lichtenfels, supra note 2, at 146.

29. The Western States Water Council in 1984 estimated that the total potential claims of tribes in 14 western states amounted to more than 45 million acre feet. See JOSEPH L. SAX ET AL., LEGAL CONTROL OF WATER RESOURCES 873 (2d ed. 1991).

30. 373 U.S. 546 (1963).

31. Id. at $600-01$.

32. For a discussion, see Burness et al., United States Reclamation Policy and Indian Water Rights, 20 NAT. REs. J. 807 (1980).

33. See Arizona v. California, 373 U.S. at 596. The five relevant tribes are the Colorado River, Chemehuevi, Ft. Mojave, Quechan, and Cocopah tribes. See id. 
award to five tribes with a collective population of less than $100,000^{34}$ amounts to roughly $1 / 15$ th of the Colorado River's flow, a flow on which some 15 million people in 7 states depend at least in part. ${ }^{35}$

Exacerbating the conflict is the fact that, under Arizona v. California, the impact from exercise of Indian water rights cannot be dispersed among out-of-state users. Because the Court determined that quantities of water awarded to tribes would count against the total supply of water apportioned to states under interstate compacts, ${ }^{36}$ states are limited in their ability to find alternative sources for existing users by their compact delivery obligations. Accordingly, it would be unsurprising if states attempted to enforce their general barriers to interstate water marketing against the tribes. ${ }^{37}$

\section{The Reason for the Difference}

Some umight claim that the conflicts under current doctrine between Indian water rights on the one hand and state imterests on the other are simply too great to justify perpetuating the favored position attaching to Indian water rights. ${ }^{38}$ But historical treatment of Indian peoples provides a potent rebuttal to claims of unfairness by states and existing users, many of whom are arguably responsible for the quandary in which they now find themselves. ${ }^{39}$ Indeed, the federal judicial development of Indian water doctrine

34. See Bureau of Indian Affairs, Local Estimates of Resident Indian Population and Labor Force Status (visited Apr. 19, 1999) <http://www.doi.gov/bia/ifcons95.html>.

35. This figure represents an estimate based on census data for the various communities relying at least in part on water from the Colorado River.

36. See 373 U.S. at 601 . For more discussion of interstate compacts, see infra text accompanying notes 53-61.

37. State responses to proposals to authorize marketing reinforce this conclusion. See infra note 176.

38. This, in fact, appears to be the position Justice O'Connor adopted in her pre-recusal draft majority opinion in Wyoming v. United States, 492 U.S. 406 (1989). There, she argued that greater "pragmatism" and "[s]ensitivity to the impact on [non-Indian] prior appropriators" was needed in awarding Indian water rights. David $\mathrm{H}$. Getches, Conquering the Cultural Frontier: The New Stbjectivism of the Supreme Court in Indian Law, 84 CALIF. L. REV. 1573, 1640-41 (1996). As Professor Getches notes, this opinion would have altered established doctrine and potentially undermined many tribal water claims. See id. at 1640. Because Justice O'Connor recused herself, however, the lower court decision was simply affirmed without opinion. See id. at 1641.

It is important to note that marketing of Indian water rights has the potential to dilute such conflicts. Because a marketed right only need be delivered downstream, existing local users may rely on their return flow to supply water for the downstream purchaser of Indian water rights. This provides existing users with a degree of flexibility that would not exist if a tribe were to use its water rights onreservation, because return flows from on-reservation use might be dispersed or otherwise difficult to appropriate. (This will be especially true if there is a large amount of regulated storage downstream from the reservation locality, since storage facilities allow balancing seasonal fluctuations in flow.)

39. See supra note 26. 
rests in great part on a more general theme in Indian law doctrine: the importance of an Indian homeland free from state control..$^{40}$

Perhaps the clearest statement of this came in Justice Stewart's dissent in Colorado River Water Conservation District v. United States, ${ }^{41}$ where he noted, "This Court has long recognized that " $\mathrm{t}]$ he policy of leaving Indians free from state jurisdiction and control is deeply rooted in the Nation's history." ${ }^{42}$ But Winters $v$. United States ${ }^{43}$ itself, viewed in tandem with federal Indian law, can be seen as laying the foundation for tribal water independence.

Winters, the seminal reserved rights decision, tied tribal water rights to the purposes of the reservation-i.e., to the "policy of the Government" and "desire of the Indians" for the tribes to become a "pastoral and civilized people." 44 As the Court in Arizona v. California put it, "[t]he Court in Winters concluded that the Government . . . intended to deal fairly with the Indians by reserving for them the waters without which their lands would have been useless."45 In other words, Indian water rights are an essential element of the reservation, as much a part of the reservation as the land itself.

As such, so long as their use is "consistent with the reservation's purpose," sovereignty doctrine would shield transactions in Indian water rights from state law. Before exploring the doctrine of tribal sovereignty, however, it is worth inquiring into whether Indian water marketing might be immune from state restraints under a more generally-applicable jurisprudence: that springing from the dormant Interstate Commerce Clause.

II

\section{IMPACT OF THE COMMERCE Clause}

The Constitution vests in Congress the power "[t]o regulate Commerce with foreign Nations, and among the several States, and with

40. For discussion and development of the concept of the reservation as homeland, see, for example, Getches, supra note 2, at 543 ("The overall purpose of virtually all Indian reservations is to provide a permanent homeland where a tribe can be economically self-sufficient and govern itself.").

41. 424 U.S. 800 (1976).

42. Id. at 826 (Stewart, J., dissenting) (quoting McClanahan v. Arizona State Tax Comm'n, 411 U.S. 164, 168 (1973)). Stewart dissented from the Court's holding that the McCarran Amendment applied to Indian water rights and thus subjected them to adjudication in state courts.

43. 207 U.S. 564 (1908).

44. Id. at 576 .

45. Arizona v. California, 373 U.S. 546,600 (1963).

46. For the case that marketing is consistent with the reservation's purpose-a casc on which this Comment relies-see Storey, supra note 2. The "consistent with the reservation's purpose" requirement might be conceived of as an "internal" constraint on the markctability of an Indian watcr right-a restraint inherent in the nature of the right itself. The state restraints discussed in this Comment, on the other hand, might be seen for conceptual purposes as "external," imposed on the right from without. 
the Indian Tribes." ${ }^{47}$ The Supreme Court has attributed different meanings to the various sub-clauses of the Commerce Clause. Those different meanings have important implications for states' abilities to inhibit Indian water marketing.

\section{A. The Interstate Commerce Clause}

The Interstate Commerce Clause is more than a positive grant of authority to Congress. It also has a negative, or "dormant," component that voids state legislation found to impermissibly burden interstate commerce. ${ }^{48}$ In fact, the Supreme Court has already applied the dormant Interstate Commerce Clause to void state restraints on water marketing, in the context of groundwater. In Sporhase v. Nebraska ${ }^{49}$ the Court struck down a Nebraska statute that effectively banned the interstate sale of groundwater. The Sporhase Court found that water was an article of commerce, and as such subject to the restraints of the dormant Interstate Commerce Clause. ${ }^{50}$

At first blush, Sporhase would seem to decide the issue raised herestates could no more prevent interstate marketing of Indian water rights than they could the marketing of any other water right. Sporhase, however, dealt with groundwater. The water rights in question here are surface waters, many of which are more heavily regulated than groundwaters, and are subject to interstate compacts. Some have argued that Sporhase does not apply to such waters because the series of interstate compacts and federal statutes applying to surface waters implicitly authorize state action to control interstate water marketing. ${ }^{51}$

Moreover, even if the implicit-authorization-by-compact theory does not hold up, Sporhase itself left room for state regulation of exports under conditions of severe shortage.$^{52}$ Consequently, as noted below, states imight still claim that they are entitled to prevent interstate marketing of Indian water rights under the dormant Interstate Commerce Clause.

47. U.S. ConsT. art. I, § 8, cl. 3 .

48. The Court first discussed the dormant aspect of the Commerce Clause in Gibbons v. Ogden, 22 U.S. (9 Wheat.) 1 (1824).

49. 458 U.S. 941 (1982).

50. See id. at 954 . The Court did not, however, categorically reject the possibility that a state might be authorized to ban exports of water. See infra note 65 and accompanying text.

51. See, e.g., Howard K. Holme, Obstacles to Interstate Transfers of Water: Many a Slip 'Twixt the Cup and the Lip, in Tradition, Innovation and Conflict: Perspectives on Colorado WATER LAw 267 (Lawrence J. MacDonnell ed., 1986); Sharon P. Gross, The Galloway Project and the Colorado River Compacts: Will the Compacts Bar Transbasin Water Diversions?, 25 NAT. RESOURCES J. 935 (1985).

52. See 458 U.S. at 956; see also infra text accompanying notes 65-70. 


\section{Implicit Authorization by Compact?}

Interstate compacts ratified by Congress are federal law, and as such may authorize state action that otherwise would conflict with the dormant Commerce Clause..$^{53}$ And in Intake Water Co. v. Yellowstone River Compact Commission, ${ }^{54}$ the court held that the Yellowstone River Compact, ${ }^{55}$ to which Congress consented in 1951, did just that. But the Yellowstone Compact included explicit language authorizing state action to prohibit export of waters from the Yellowstone basin. ${ }^{56}$ As such, it was consistent with language in Sporhase noting that, in those instances where the Court recognized congressional authorization of state laws that conflicted with the dormant Commerce Clause, "Congress' intent and policy to sustain state legislation from attack under the Commerce Clause was expressly stated." 57

Nonetheless, some commentators urge, and not without some force, that the compacts applicable to the area in question in Sporhase differ from the more sweeping compacts that captivate most water law observers. In particular, they urge that the language of the Colorado River Compact authorizes states to prevent interstate marketing of water that is apportioned to a state under that Compact and its offspring. ${ }^{58}$

These commentators rely on both the text of the Colorado River Compact itself and on records of proceedings leading up to its formation and execution. Their argument appears to turn chiefly on two provisions of the Compact: Article III(a), which gives to each basin the "exclusive beneficial consumptive use" of waters apportioned to it, and Article VIII, which says that all rights to beneficial use must be "satisfied solely from the water apportioned to that Basin in which they are situated." ${ }^{59}$ Moreover, the argument distinguishes the language in the Colorado River Compact from the language of the compacts explicitly named by the Court in Sporhase. ${ }^{60}$ Finally, the argument notes that Sporhase did (albeit in the process of enumerating a number of factors that might come into play "in

53. See Intake Water Co. v. Yellowstone River Compact Comm'n, 769 F.2d 568, 569-70 (9th Cir. 1985).

54. Id.

55. 65 Stat. 663 (1951).

56. See 769 F.2d at 569 .

57. Sporhase, 458 U.S. at 960.

58. See Gross, supra note 51. A variant of this position suggests that while the Colorado River Compact's text cannot be read as posing an obstacle to interstate transfers, and while the framers of the Compact could not have so intended because they acted before Sporhase, the Compact should nonetheless be construed as including an implied term forbidding interstate marketing. See David Elliott Prange, Note, Regional Water Scarcity and the Galloway Proposal, 17 ENvTL. L. 81, 95 (1986).

59. Gross, supra note 51 , at 940,943 (emphasis in original). It is worth noting that the Compact refers to basins, not states This suggests that, even if one grants the implicit-authorization-by-compact theory, marketing within a particular basin might face fewer barriers than trans-basin marketing.

60. See id. at 954. 
times of severe shortage") recognize that "under certain circunstances" a state may restrict water within its borders, and that the Court cited the existence of interstate compacts as fostering a "legal expectation" to this effect. ${ }^{61}$

These arguments, however, were not unfamiliar to the Sporhase Court. Indeed, the Court devoted an entire section of its opinion to the rebuttal of the implicit-authorization argument presented by the parties. ${ }^{62}$ One might contend, of course, that this discussion amounts to no more than dicta because Sporhase dealt with groundwater, whereas the compacts tendered for the Court's consideration related to surface waters. This Comment, however, views Sporhase as controlling. Regardless of one's views, it is clear that the Supreme Court has considered the argument that surface water compacts implicitly authorize state restraints on interstate water marketing, and it has rejected that argument in favor of a standard requiring "express" congressional abrogation of the dormant Interstate Commerce Clause. Whether the Court will revisit that holding is anyone's guess.

This is not, however, meant to demean the importance of the implicitauthorization issue-it is tremendously controversial, and the states' view that compacts establish unalterable state entitlements to water is quite understandable given the history of western water apportionment and development. Because states governed by interstate compacts are entitled to only the amount of water given them by the relevant compact, any transfer of water across state lines by a private party will extinguish the right to use that water within the state by anyone else. And because water used by Indian tribes is counted against the apportionment of the state im which the

61. See Sporhase, 458 U.S. at 956.

62. See id. at 958-60 (section III). Nebraska did not limit its compact argument to the two surface water compacts applicable to the area in question (though not applicable, of course, to the dispute before the Court, which dealt only with groundwater). Instead, it relied on the "system of inter-State compacts which have been enacted by the States and approved by Congress on many of the rivers and waterways of the nation" in support of its claim that these compacts "exempted water from application of the Commerce Clause." Brief of Appellants at 25, Sporhase, 485 U.S. 941 (No. 81-613).

The Sporhase Court was well aware of the fact that different compacts spoke in different terms when it chose to require explicit congressional approval of restraints on exports. The amicus brief of Colorado, et al. drew the Court's attention to both the Colorado River Compact and Upper Basin Compact on the one hand, which the amici alleged implicitly authorized states to limit water apportioned to them to use within their boundaries, and to the Yellowstone River Compact on the other, where the Compact spoke explicitly. See Brief of Amici Curiae: States of Colorado, Wyoming, Utah, Nevada, Kansas, North Dakota, South Dakota, and Missouri at 7-9, Sporhase (No. 81-613). Importantly the brief quoted the "exclusive beneficial use" language from Article III(a) of the Colorado River Compact relied upon by those who argue in favor of implicit compact authorization. See supra text accompanying supra note 59. 
reservation resides, ${ }^{63}$ the "threat" to state compact entitlements from Indian water marketing is no less great than it is from state-law appropriators. ${ }^{64}$

\section{The Shortage Exception-State Reactions to Sporhase}

While the implicit-authorization-by-compact theory has some theoretical force, it is clear that the states themselves are not taking any chances on that theory. Instead, most states have amended their export statutes to take advantage of a passage in Sporhase suggesting that barriers to interstate marketing might withstand dormant Interstate Commerce Clause scrutiny if they meet several criteria and apply "in times of severe shortage." 65

Different states have taken different approaches in response to Sporhase. Broadly speaking, they fall into two categories: continuation of regulatory bans responsive to the "shortage" language discussed above," and implementation of a state water bank whereby the state takes advantage of the larger market-participant exception to the dormant Interstate Commerce Clause. ${ }^{67}$

Whether the shortage statutes could meet Sporhase's requirement is arguable. Colorado, for instance, is far from a water shortage; depending on the year, from 500,000 to nearly a million acre feet of the state's

63. See the discussion of Arizona v. California at supra text accompanying note 36 .

64. In fairness to advocates of restraining interstate water marketing to preserve the integrity of a state's compact apportionment, it is worth noting that considerations of geography may complicate the economic assessments that are often relied upon to justify interstate water marketing. Suppose, for example, that a water user in an economically depressed sub-basin decidcs that it is in hest intcrest to sell water across state lines rather than continue to use it in the state. If this would result in a more efficient use of water, economics would seem to celebrate the transfer.

But states often have many different sub-basins within the larger basin governed by compacts. Colorado, for example, has four large sub-basins which all drain separately into the Colorado River system. And many of these sub-basins themselves have sub-basins which may provide different economic environments for water use. It might well be possible, therefore, for someone in a different sub-basin within the state to make a use of the water within the state that would be just as justified economically as the use across state lines.

Economic efficiency also, of course, ignores the central premise underlying the compacts and much of state water law itself: that "water is the lifeblood of the west," and is central to a state's economic development. Consequently, the state of origin will prefer even a comparativcly uneconomic use of water within its borders, so long as its use results in all of the economic multipliers attached with water use ricocheting within the state itself. The "beneficial use" requirement of state water law that mandates economic uses of water reflects state recognition that water is essential to cconomic growth.

It does not necessarily follow, however, that an exportation of water will inevitably result in a reduction of eeonomic activity within the state. The selling party, for instance, might invest the revenue from sale of the water within the state, or a state might find water from alternative sources. But the transfer could entail large costs for the state nonetheless, by foreing it to look elsewhere to fuel its own future growth.

65. Sporhase, 458 U.S. at 956.

66. States following this general approach include, for example, Colorado and New Mexico. See Colo. Rev. Stat. AnN. § 37-81-101 (West 1998); N.M. Stat. ANN. § 72-12B-1 (Michie 1998).

67. Montana is the first state to have developed such a program. See MONT. CODE ANN. $\$ 85-2-$ 311 (1997). 
compact entitlement has remained unused in recent years. ${ }^{68}$ Nonetheless, courts have been fairly solicitous of export ban statutes enacted since Sporhase. In El Paso v. Reynolds, ${ }^{69}$ the court recognized that the concept of shortage could incorporate some reference to future projections: "It would be unreasonable to require a state to wait until it is in the midst of a dire shortage before it can prefer its own citizens' use of the available water over out-of-state uses." 70

Consequently, a number of states in which Indian reservations are located continue to restrict marketing of water across state lines. ${ }^{71}$ While it is uncertain whether or not some of these statutes could withstand judicial challenge, their very presence inhibits abilities to consummate marketing transactions. Because any transaction would likely turn on the success of a court battle over the enforceability of an export statute, the pool of potential purchasers is likely to be slim indeed. Consequently, regardless of their legal merit, these export statutes are likely to substantially chill interstate marketing.

Tribes seeking to market their water are not, however, limited to raising a challenge to state export bans, however constituted, under the dormant Interstate Commerce Clause. By virtue of their status as sovereign entities, they may challenge state export bans under the Indian Commerce Clause and related sovereignty doctrine as well.

\section{B. The Indian Commerce Clause and Tribal Sovereignty}

Indian tribes enjoy a limited sovereignty; while entirely defeasible by Congress, tribal sovereignty protects most on-reservation activities from state interference. ${ }^{72}$ In addition, the U.S. Constitution's Indian Commerce Clause provides an independent but related barrier to imposition of state authority over tribal activities. ${ }^{73}$ Historically, the Indian Commerce Clause and sovereignty doctrine represented a formidable shield against state regulation of tribal activities, providing a near-total barrier to the operation

68. See Ellen Miller, Transfer of River Water an Issue: Many Say Babbitt Has No Authority, Denver Post, Dec. 20, 1997, at B1.

69. 597 F. Supp. 694 (D.N.M. 1984).

70. Id. at 701 .

71. See, e.g., ARIz. Rev. Stat. AnN. § 45-292 (West 1998); Colo. Rev. Stat. ANn. § 37-81101; IdaHo Code \$ 42-401 (Michie 1996); KAN. STAT. ANN. § 82a-726 (1998); N.M. STAT. ANN. § 72-12B-1 (Michie Supp. 1998); OKLA. Stat. ANN. tit. 82, § 1085.2 (West 1998); OR. Rev. STAT. § 537.810 (Supp. 1998); UTAH Code ANN. § 73-3a-108 (Lexis Supp. 1998); Wash. Rev. Code ANN. § 90.03.300 (West 1998); Wyo. STAT. ANN. \$ 41-3-115 (Michie 1998).

72. See United States v. Wheeler, 435 U.S. 313,323 (1978).

73. In the "foundation" period of federal Indian law presided over by Justice John Marshall, the Supreme Court viewed the Indian Commerce Clause as informing the actual notion of tribal sovereignty itself. See Cherokee Nation v. Georgia, 30 U.S. (5 Pet.) 1, 18 (1831). Today, however, the two are seen as "independent but related" barriers to the assertion of state authority. See White Mountain Apache Tribe v. Bracker, 448 U.S. 136, I42 (1980). 
of state law on reservations..$^{74}$ The past ten years, however, have witnessed a fairly substantial retrenchment in Indian law sovereignty jurisprudence. ${ }^{75}$

Still, it is fairly well-settled that states cannot directly tax or regulate the on-reservation, intra-tribal activities of Indian tribes or tribal members without explicit congressional authorization. ${ }^{76}$ Consequently, two important features of an interstate Indian water marketing transaction shape the discussion that follows. First, interstate Indian water marketing transactions will almost invariably involve non-Indians. Thus, if the state is able to regulate the non-Indian party to the transaction, it will also be able to regulate the tribes indirectly. Second, interstate water marketing necessarily involves delivery and use of water off-reservation. Marketing therefore raises the question of whether or not a marketing transaction should be viewed as taking place on- or off-reservation. Either one of these issues alone may be sufficient to remove sovereignty protections from interstate Indian water marketing transactions.

\section{On-Reservation Transactions Between Tribes and Non-Indians}

One strategy that a state attempting to thwart interstate marketing of Indian water rights might pursue would be to indirectly limit tribal attempts to market water by taxing or otherwise regulating the non-lndian purchasers of tribal water rights. The Supreme Court has, in general, been more indulgent of state regulation and taxation of non-Indians, even for on-reservation activities.

This was not always the case. Over the past ten years, the Court's sovereignty doctrine has grown muddied and generally evolved in a direction unfavorable to the tribes. ${ }^{77}$ The roots of this trend, according to commentators, lies in the Court's abandonment of "foundation principles" in favor of a looser balancing test. ${ }^{78}$ One commentator argues that today the Court will use whatever test best serves its subjective view of the correct

74. The Supreme Court has never explicitly held that the Indian Commerce Clause operates in a "negative" or "dormant" capacity to invalidate state legislation as does the Interstate Commerce Clause. See Philip P. Frickey, Congressional Intent, Practical Reasoning, and the Dynainic Nature of Federal Indian Law, 78 CALIF. L. Rev. 1137, 1168-69 n.179 (citing Cotton Petroleum Corp. v. New Mexico, 490 U.S. 163, 109 S. Ct. 1698, 1713-15 (1989)). Nonetheless, the Court has relied on the Indian Commerce Clause, in connection with more general principles of tribal sovereignty, to sharply limit state intrusions on tribal activities. See Getches, supra note 38, at 1577-86.

75. See generally Getches, supra note 38. For the sake of brevity, I refer to the barriers posed by the Indian Commerce Clause and related sovereignty jurisprudence with the conceptual label "sovereignty" in the discussion that follows.

76. See, e.g., McClanahan v. Arizona State Tax Comm'n, 411 U.S. 164 (1973); Bracker, 448 U.S. at 144.

77. See Getches, supra note 38 , at 1575.

78. See, e.g., William C. Canby, The Status of Indian Tribes in American Law Today, 62 WasH. L. Rev. 1, 22 (1987); Getches, supra note 38, at 1575; Judith V. Royster \& Rory SnowArrow Fausett, Control of the Reservation Environment: Tribal Primacy, Federal Delegation, and the Limits of State Intrusion, 64 WASH. L. REv. 581, 649-57 (1989). 
result in the case. ${ }^{79}$ Rather than repeat the historical evolution of the Court's jurisprudence in this area, a task ably accomplished elsewhere, ${ }^{80}$ the discussion that follows focuses on those cases with the most potential to bear on the interstate marketing problem. The discussion examines cases involving both state regulation and state taxation of activities with links to tribes. Both issues are relevant to the problem of Indian water marketing, since a state might accomplish its regulatory objectives just as effectively through imposition of a prohibitively burdensome tax on an interstate water marketing transaction.

McClanahan v. Arizona State Tax Commission ${ }^{81}$ is the textbook starting point for a discussion of the Court's modern sovereignty jurisprudence. In McClanahan, Arizona sought to impose its personal income tax on reservation Indians whose sole source of income came from reservation sources. ${ }^{82}$ The Court, per Justice Marshall, professed continuing faithfulness to the landmark statement in Williams $v$. Lee $e^{83}$ that "absent governing Acts of Congress, the question has always been whether the state action infringed on the right of reservation Indians to make their own laws and be ruled by them." ${ }^{\prime 34}$ But for the first time, the Court emphasized that the issue of Indian sovereignty turned largely on a special breed of preemption: "The modern cases ... tend to avoid reliance on platonic notions of Indian sovereignty and to look instead to the applicable treaties and statutes which defime the limits of state power." 85

Although McClanahan dealt with state regulation of Indians themselves, it laid the groundwork for cases concerning state regulation or taxation of non-Indians as well. ${ }^{86}$ Perhaps the clearest indication of this came in another Marshall opinion, White Mountain Apache Tribe $v$. Bracker. ${ }^{87}$ There, the Court barred Arizona from imposing fuel and motor carrier taxes on a non-Indian logging company operating on the reservation. Bracker is perhaps the leading modern sovereignty decision; it clarified that McClanahan did not erase the potential for sovereignty principles to shield tribes from state regulation independent of preemption:

Congressional authority [under the Indian Commerce Clause] and the "selm-independent position" of Indian tribes have given rise to two independent but related barriers to the assertion of state regulatory authority over tribal reservations and members. First, the

79. See generally Getches, supra note 38.

80. See sources cited supra note 78.

81. 411 U.S. 164 (1973).

82. Unlike the facts under consideration here, then, McClanahan involved enrolled tribal members rather than non-Indians.

83. 358 U.S. 217 (1959).

84. Id. at 220.

85. McClanahan, 411 U.S. at 172.

86. See Getches, supra note 38, at 1591.

87. 448 U.S. 136 (1980). 
exercise of such authority may be preempted by federal law. Second, it may unlawfully infringe on the right of reservation Indians to make their own laws and be ruled by them. The two barriers are independent because either, standing alone, can be a sufficient basis for holding state law inapplicable to activity undertaken on the reservation or by tribal members. ${ }^{88}$

The Court did note, however, that the two barriers were relatcd in the sense that notions of tribal sovereignty should serve as a "backdrop" in the preemption inquiry. ${ }^{89}$

Bracker also inaugurated what courts have come to apply as a balancing test in cases involving regulation of non-Indians engaging in activities on reservations: In such cases, the Court will conduct "a particularized inquiry into the nature of state, federal, and tribal interests ... to determine whether, in the specific context, the exercise of state authority would violate federal law." $"$ The Court originally applied this test when there was no explicit preemption..$^{91}$ But in subsequent cases it has applied the test irrespective of the preemption background. ${ }^{92}$

The following discussion first examines lower court application of Bracker to the question of state control over water rights on reservations. It then compares Supreme Court application of Bracker in factually parallel contexts.

\section{a. Application of the Bracker Test to Indian Water Disputes Generally}

The Supreme Court has not spoken to the operation of state water law on Indian reservations, much less to the specific question of interstate marketing of Indian water. Two Ninth Circuit decisions from the early 1980s are widely viewed as the leading cases that address the application of state water laws on reservations; their utility in evaluating water marketing is, however, somewhat limited. ${ }^{93}$

88. Id. at $142-43$ (internal punctuation omitted).

89. See id. at 143.

90. Id. at 145 .

91. See Califomia v. Cabazon Band of Mission Indians, 480 U.S. 202, 214-16 (1987).

92. See, e.g., Department of Taxation and Fin. v. Milhelm Attea \& Bros., 512 U.S. 61 (1994).

93. Naturally, a number of other cases also touch on state authority vis-à-vis Indian water rights. Predictably, a number of these address the question of whether the McCarran Amendment provides states with regulatory as well as adjudicatory authority over Indian water rights. Those courts addressing this question have almost uniformly ruled that it does not. See, e.g., South Delta Water Agency v. United States, 767 F.2d 531, 542 (9th Cir. 1985); In re Benefieial Water Use Permit, 923 P.2d 1073, 1084 (Mont. 1996) (Leaphart, J., concurring); see also Colville Confederated Tribes v. Walton, 647 F.2d 42, 53 (9th Cir. 1981) (rejecting without explanation the applicability of the McCarran Amendment).

The Wyoming Supreme Court has addressed the question of whether tribes may market their reserved water rights. See In re General Adjudication of All Rights to Use Water in the Big Horn River System, 753 P.2d 76 (Wyo. 1988). Although it did not specifically rule on the question, the court upheld a district court order forbidding export. See $i d$. at 100 . The dissents in the case, however, indicate that the court based its conclusion on the inherent nature of the reserved right itself, not on 
The first, Colville Confederated Tribes $v$. Walton,${ }^{94}$ involved a nonIndian owner of allotted land on the Colville reservation who attempted to enforce state-based water rights in the No Name stream system. Critically, the No Name system lay entirely within the boundaries of the Colville reservation.

The court relied on Bracker to hold that the state had no power to regulate water in the No Name system: "State regulatory authority over a tribal reservation inay be barred either because it is pre-enpted by federal law, or because it unlawfully infringes on the right of reservation Indians to self-government. ${ }^{\times 55}$ The court resolved the question on the first of these grounds, finding that creation of the Colville reservation preempted state authority. As background to the question of preemption, the court noted that tribal sovereignty affords tribes authority over non-Indians within reservation boundaries when non-Indian conduct threatens or has some direct effect on the health and welfare of the tribe. ${ }^{96}$ The court noted that "in arid and semi-arid regions of the West, water is the lifeblood of the community," and held that conduct involving tribal water rights thus implicated tribal welfare. ${ }^{97}$

In addressing preeniption, the court relied on the Supreme Court's opinion in Federal Power Commission v. Oregon ${ }^{98}$ for the general proposition that water use on a federal reservation is not subject to state regulation absent explicit federal recognition of state authority. ${ }^{99}$ It then cited an earlier Ninth Circuit case, United States v. McIntire ${ }^{100}$ which held state law not controlling on Indian reservations specifically. ${ }^{101}$ The Walton court did, however, explicitly acknowledge that because the No Name systein resided entirely within the boundaries of the Colville reservation, it made the case "easier than it otherwise might be."102

Three years after Walton, the Nimth Circuit revisited the applicability of state water law on Indian reservations in United States $v$. Anderson. ${ }^{103}$ Here, the court reached a strikingly different conclusion. Anderson involved a general adjudication of water rights in the Chamokane Basin in Washington. The State of Washington sought to exercise regulatory

some external prohibition imposed by the state. As such, the court rested its conclusion on the opposite premise from that upon which this Comment rests: that there is no inherent limitation on the marketability of tribal reserved rights. Compare Storey, supra note 2.

94. 647 F.2d 42 (9th Cir. 1981).

95. Id. at 51 (citing Bracker, 448 U.S. at 143).

96. See id. at 52 .

97. Id.

98. 349 U.S. 435 (1955).

99. See Walton, 647 F.2d at 52-53.

100. 101 F.2d 650 (9th Cir. 1939).

101. See id.; see also Walton, 647 F.2d at 53.

102. Walton, 647 F.2d at 53.

103. 736 F.2d 1358 (9th Cir. 1984). 
authority over non-Indian allottees within the Spokane reservation who were using excess water within the system. The tribe claimed that Walton precluded the exercise of state authority even over non-Indians on nontribal land within the reservation. The court disagreed, holding that state water law did apply to non-Indian water users on a reservation when the stream system at issue transcended reservation boundaries.

The Anderson court applied the Bracker "particularized inquiry" test. It concluded that, unlike in Walton, allowing state regulation of non-Indian water use on the reservation did not pose a threat to tribal government or welfare. The non-Indian water rights at issue in Anderson were junior to tribal rights, so their exercise would not infringe tribal water use. Nor did the tribe have any "consensual agreement between the non-Indian water users and the Tribe which would furnish the basis for the implication of tribal regulatory authority." 104

In assessing state interests, the court noted, "[t]he weight of the state's interest depends, in large part, on the extent to which waterways or acquifers transcend the exterior boundaries of Indian country." 105 Because the boundaries of the water system at issue in Anderson transcended the reservation, the court found that the state had an important interest in integrating non-Indian water rights on the reservation with non-Indian water rights elsewhere in the system. ${ }^{106}$

Neither Walton nor Anderson has especially great predictive value for the question of Indian water marketing. Walton, as the court recognized, involved the peculiar factual scenario of an intra-reservation stream. As such, not only did it not involve state administration over non-tribal portions of the stream, but it also did not implicate any interstate compacts. But while Anderson would seem to establish a strong state interest in stream systems exceeding reservation boundaries (a condition that will, of course, hold in any interstate Indian water marketing transaction), the Anderson court made clear that its holding allowed the state only to regulate state-based non-Indian rights and not tribal water rights. ${ }^{107}$ Moreover, the tribe and any potential purchaser, contra Anderson, would have a fairly elaborate "consensual arrangement" governing their water marketing transaction, an arrangement that state interference might frustrate. Finally, both Walton and Anderson involved states seeking to exercise authority over their own citizens. In an interstate marketing transaction, on the other hand, the state would be attempting to regulate out-of-state citizens in order to benefit its own residents.

104. Id. at 1365 (citing Montana v. United States, 450 U.S. 544, 566 (1981)).

105. Id. at 1366.

106. See id.

107. See id. at 1365. 
Most importantly, of course, Walton and Anderson are both merely circuit court opinions preoccupied with the dispute before them. By contrast, Supreme Court precedent in other factual areas provides a fairly rich account of how it might view an attempt by states to preclude interstate marketing of Indian water.

\section{b. Supreme Court Sovereignty Precedent Since Bracker}

A number of relatively recent Supreme Court Indian sovereignty decisions are potentially relevant to assessing whether tribes may market water interstate. The Court's application of the Bracker test has, to be sure, drawn fine factual distinctions, and produced alignments of Justices that can seem difficult to reconcile. ${ }^{108}$ But some of the factual distinctions the Court has drawn are actually informative in the case of water marketing. Indeed, since so much of the law in this area hes in the facts of the cases, the discussion that follows immediately below lays out in some detail case histories that might be relevant by analogy to the water marketing imquiry. The following Part then seeks to apply the lessons of these cases-both in terms of facts and rules - to the case of interstate Indian water marketing.

An obvious starting point is the Bracker case itself. As would be the case in a water marketing transaction, Bracker involved a cooperative effort between a tribe and non-Indians. There, the non-Indian party was a lumber company conducting on-reservation timber harvesting. The Court began its analysis by noting the heavily federalized nature of tribal timber harvesting, which involved federal statutes, federal regulations, and approval of timber contracts between non-Indian companies and tribes by the Bureau of Indian Affairs. ${ }^{109}$ This federal involvement, the Court found, overlaid a "policy of assuring that the profits derived from timber sales will inure to the benefit of the Tribe, subject only to administrative expenses incurred by the Federal Government," a policy linked to "the general federal policy of encouraging tribes to revitalize their self-government and assume control over their business and economic affairs."110

Opposed to this heavy federalization and concomitantly weighty policy interest, the Court found weak state interests in taxation. The nonIndian activities at issue occurred entirely within reservation boundaries, and thus did not implicate any provision of state services that taxation would serve. ${ }^{111}$ Consequently, state authority was preempted.

Justice Marshall authored yet another important opinion for present purposes in New Mexico v. Mescalero Apache Tribe. ${ }^{112}$ There, the tribe had

108. See Getches, supra note 38 , at 1608.

109. See Bracker, 448 U.S. at 145-48.

110. Id. at 149.

111. See id. at 150.

112. 462 U.S. 324 (1983). 
established a comprehensive scheme for managing the reservation's fish and wildlife resources, and had received significant assistance and approval from the Department of the Interior. The tribe's ordinances specified that even non-Indians need not have state hunting and fishing licenses to pursue those activities on the reservation. Nonetheless, New Mexico enforced its own regulations against non-Indians taking game on the reservation.

A unanimous Court applied Bracker, but with a hint of the outright balancing approach to come in later cases: "State jurisdiction is preempted by the operation of federal law if it interferes or is incompatible with federal and tribal interests reflected in federal law, unless the State interests at stake are sufficient to justify the assertion of State authority." 113 Moreover, the Court noted, "when a tribe undertakes an enterprise under the authority of federal law, an assertion of State authority must be viewed against any interference with the successful accomplishment of the federal purpose." "114 Finally, in assessing state interests, the court advised, "[t]he exercise of state authority which imposes additional burdens on a tribal enterprise must ordinarily be justified by functions or services performed by the State in connection with the on-reservation activity," and "[a] State's regulatory interest will be particularly substantial if the State can point to off-reservation effects that necessitate State intervention."115

Applying those principles in Mescalero was easy. The state could point to neither services it rendered in connection with on-reservation hunting and fishing, nor to off-reservation effects caused by such activities on-reservation. ${ }^{16}$ On the other side was a pervasive framework of federal/tribal cooperation conducted pursuant to federal statute. ${ }^{117}$ Because

113. Id. at 334.

114. Id. at 336 .

115. Id.

116. See id. at $341-43$.

117. Importantly, the Court in Mescalero discussed the impact of Public Law 280. That Act grants limited criminal and civil jurisdiction over Indian reservations to states, but it contains provisions expressly excluding authority both over the hunting and fishing at issue in Mescalero, and over water. See 18 U.S.C. § 1162(b) (1998); 25 U.S.C. \& 1321(b) (1998) (hunting \& fishing); 25 U.S.C. § 1322(b) (1998); 28 U.S.C. $\S 1360$ (b) (1998) (water). The Court found that this exclusion "evidences Congrcss' understanding that tribal regulation of hunting and fishing should generally be insulated from state interference..." Mescalero, 462 U.S. at 340 n. 25.

It is important to note, however, that the Court has handed down decisions in the area of tribal fishing that might be seen as opening a greater window to state authority. In particular, a series of cases dealing with rights to anadromous fisheries in the Pacific Northwest have recognized state authority to regulate even some on-reservation tribal aetivities in the interests of conservation. See Washington v. Washington State Commercial Passenger Fishing Vessel Ass'n, 443 U.S. 658, 682-85 (1979); Puyallup Tribe v. Department of Game, 433 U.S. 165, 173-77 (1977) [Puyallup III]; Department of Game v. Puyallup Tribe, 414 U.S. 44, 48-49 (1973) [Puyallup II]; Puyallup Tribe v. Department of Game, 391 U.S. 392, 398-99 (1968) [Puyallup I]. Because these cases involve a somewhat fugitive resource, a court might find them helpful for purposes of analyzing a water marketing dispute. Sevcral considerations, however, seem to limit their applicability to water marketing. 
"concurrent jurisdiction would effectively nullify the Tribe's authority to control hunting and fishing on the reservation," "118 state law was preempted.

Less than one month after the decision in Mescalero, however, the Court adopted a much more limiting approach in Rice v. Rehner. ${ }^{119}$ The tone of deference to tribal sovereignty present in Bracker and Mescalero is noticeably absent in Justice O'Connor's opinion in Rehner. There, the Court held that California could apply its liquor-licensing laws to a federally-licensed Indian trader seeking to sell liquor on the Pala Reservation in San Diego. The Court noted that where there has been a tradition of sovereign immunity, the Court will be reluctant to infer state authority to the contrary absent express congressional language. ${ }^{120}$ Where there is no such tradition, however, "our preemption analysis may accord less weight to the backdrop of tribal sovereignty."121

The Court began its examination of the facts in Rehner by observing that its prior jurisprudence had already made clear that states can enforce licensing requirements even on tribal members who sell to non-Indians. ${ }^{122}$ The only issue, therefore, was whether imposition of California's liquor regulation on sales to tribal members implicated interests in tribal sovereignty. Seen this way, the question was easily resolved: Not only was tribal self-government not implicated by state regulation of liquor-federal law explicitly delegated to states the responsibility to regulate certain liquor transactions in Indian country, and removed such authority from the tribes. ${ }^{123}$ Because there was no tradition of tribal self-government in the context of liquor regulation, there was no presumption in favor of finding state law preempted. ${ }^{124}$

First, all of these decisions pre-date the Court's adoption of the now-dominant Bracker test. Second, the anadromous fisheries at issue in the northwest cases seem less analogous to water rights than do the fisheries at issue in Mescalero. This is most obvious in the sense that tribal rights to anadromous fish create the potential for a tribe to extinguish the species on which all other users rely; as Justice Douglas put it in Puyallup II, "the Treaty does not give the Indians a federal right to pursue the last living steelhead until it enters their nets." See Puyallup II, 414 U.S. at 49. Accordingly, the Court's interest in those cases was in ensuring fair apportionment of the fishery resource among a wide variety of competing users. See id. at 48-49.

The same considerations are not present in water marketing. Tribes enjoy a set right to water, and their exercise of that right, either through marketing or use on reservation, cannot be said to inflict injury on other users. See supra note 18. Accordingly, Mescalero seems more apposite in the water marketing context than the northwest cases.

118. Mescalero, 462 U.S. at 338.

119. 463 U.S. 713 (1983).

120. See id. at 720 .

121. Id. at 721 .

122. See id. at $720 \&$ n.7 (citing Moe v. Confederated Salish and Kootenai Tribes, 425 U.S. 463 (1976)).

123. See id. at 722-24; see also California v. Cabazon Band of Mission Indians, 480 U.S. 202, 220 (1987) (explaining that Rehner rested on grounds that Congress "had plainly anticipated that the States would exercise concurrent authority" over liquor regulation on reservations).

124. See Rehner, 463 U.S. at 726. 
The Court decided Bracker, Rehner, and, at least nominally, Mescalero on preemption grounds. In those cases, the "particularized inquiry" test served as background to the question of preemption. Similarly, in California v. Cabazon Band of Mission Indians, ${ }^{125}$ the Court relied on Mescalero's statement that "[s]tate jurisdiction is preempted by the operation of federal law if it interferes or is incompatible with federal and tribal interests reflected in federal law, unless the State interests at stake are sufficient to justify the assertion of State authority."126 But, the Court tip-toed even closer to applying the "particularized inquiry" test as a simple balancing test. Cabazon held that both California and one of its counties were prohibited from regulating bingo and card clubs on the reservation. The clubs, a major source of tribal employment and the tribe's sole source of income, served predominantly non-Indian customers.

After establishing that federal law did not affirmatively authorize states to regulate gambling on reservations, ${ }^{127}$ the Court turned to the Bracker test as elaborated in Mescalero. The Court first noted the general federal interest, elaborated in such statutes as the Indian Financing Act of $1974^{128}$ and the Indian Self-Determination and Education Assistance Act of $1975,{ }^{129}$ in "encouraging tribal self-sufficiency and economic development." ${ }^{130}$ It then noted the Department of the Interior's heavy investment in and approval of the Department's tribal gaming facilities, and opposition to state regulation of tribal gaming. ${ }^{131}$

Importantly, the Court in Cabazon distinguished Washington $v$. Confederated Tribes of the Colville Indian Reservation..$^{132}$ In Colville, the Court had allowed the state to tax tribal smoke shops selling cigarettes to non-tribal members. ${ }^{133}$ The Cabazon Court noted that Colville turned substantially on the fact that cigarette sales involved no addition of value on the reservation, whereas gaming enterprises provided both employment to tribal members and revenue to the tribe itself. ${ }^{134}$ In this sense, the Court found, the gaming enterprises were more like the hunting resort complex at issue in Mescalero than the cigarette sales in Colville. ${ }^{135}$

125. Cabazon, 480 U.S. at 202.

126. Id. at 216 (quoting Mescalero, 462 U.S. at 334).

127. The Court distinguished regulatory state action and penological state action, holding that Public Law 280 only authorized the latter. See Cabazon, 480 U.S. at 207-12. The Court's discussion of Public Law 280 in Cabazon is not especially applicable to the water marketing question, since Public Law 280 contains an express exclusion of state jurisdiction over water. See supra note 117.

128. 25 U.S.C. $\S \S 1451-1544$ (1982).

129. Id. $\$ 450$ (1982).

130. Cabazon, 480 U.S. at 216 .

131. See id. at 217-18.

132. 447 U.S. 134 (1980).

133. See id. at 150-60.

134. I refer to this distinction in the text that follows as "the value-added distinction."

135. See Cabazon, 480 U.S. at 219-20; see also Department of Taxation and Fin. v. Milhelm Attea \& Bros., 512 U.S. 61, 73 (1994) (following Colville as to cigarette taxation and reaffirming the value- 
As of Cabazon, then, the Court has had a fairly orderly framework to govern disputes over state regulation of non-Indians engaged in reservation activities: The value-added distinction informed the "particularized inquiry" test, and broad federal and tribal interests in tribal self-sufficiency typically preempted state law in cases where value was added on the reservation. Then came the Court's decision in Cotton Petroleum Corp. v. New Mexico. ${ }^{136}$

The Cotton Petroleum Court held that New Mexico could tax nonIndian gas producers on tribal lands. ${ }^{137}$ The Jicarilla Apache tribe, the tribe in question, was not a formal party in the case. Instead, it filed a brief amicus curiae arguing that a decision upholding the state taxes would substantially interfere with the Tribe's ability to levy its own taxes, and would dimimish the desirability of on-reservation leases. ${ }^{138}$

Past cases would have seemed to indicate that tribal interests were sufficiently substantial to warrant displacement of state authority. The Court, however, rejected in Cotton Petroleum the broad tribal interests in self-sufficiency that it found sufficient in Cabazon. ${ }^{139}$ Instead, it devoted inost attention to the Indian Mineral Leasing Act of $1938 .{ }^{140}$ While the Court acknowledged that the Act intended "to provide Indian tribes with badly needed revenue," it found "no evidence that Congress intended to remove all barriers to profit maximization." 141 Moreover, the Court found that since federal law permitted state taxation of oil production on Indian reservations at the time Congress passed the 1938 Act, there was "no history of tribal independence from state taxation [in the petroleum area] to form a 'backdrop' against which the 1938 Act should be read." 142

With this statutory background, the Court found that the Bracker "particularized inquiry" test tilted in favor of the state. In assessing tribal interests, the Court relied on the District Court's conclusion that the state tax would impose no economic burden on the tribe, ${ }^{143}$ and noted that while both the Tribe and the Interior Department had detailed regulations in

added distinction). As one might expect, this "value-added" distinction is informative in an evaluation of water marketing. See infra text preceding note 171.

136. 490 U.S. 163 (1989).

137. See id. at 186 .

138. See id. at 170 .

139. See id. at $183 \mathrm{n} .14$ (stating that while the Indian Reorganization Act, the Indian Financing Act of 1974, and the Indian Self Determination and Education Assistance Act of 1975 evidence a congressional concern with fostering tribal self-government, they do not express a congressional imtent to preempt state taxation of oil and gas leases).

140. 25 U.S.C. § 396 a (1998).

141. Cotton Petroleum, 490 U.S. at 180. One commentator has characterized this approach as "turn[ing] the Court's Indian preemption analysis on its head" by starting with a presumption against preemption of state law. See Getches, supra note 38, at 1619 n.202.

142. Cotton Petroleum, 490 U.S. at 182.

143. See id. at 185 . 
place, the state had its own regulations. ${ }^{144}$ As for state interests, the Court found that, unlike in cases like Bracker, the state had actually provided some services to both the Tribe and Cotton Petroleum. The fact that the services were not even remotely proportional to the tax burden, said the Court, was not decisive. ${ }^{145}$

Obviously, Cotton Petroleum departs rather significantly from the at least plausibly coherent framework established by previous cases. Like Cabazon, Mescalero, and Bracker, Cotton Petroleum involved a resource where value indisputably derived from the reservation. And while the special considerations of Public Law 280 that were present in Mescalero were lacking in Cotton Petroleum, Cotton Petroleum firmly rejected the proposition accepted in Mescalero, Cabazon, and elsewhere that the various statutes enunciating the general goal of greater tribal independence should influence the analysis.

Unsurprisingly, commentators have rained criticism on Cotton Petroleum. Professor Frickey noted that, perhaps because the Tribe was not a formal party in lower court proceedings, "the record failed to demonstrate that payment of the tax would harm the tribe, either by effectively imposing the practical incidence of the tax on the tribe or by interfering with the tribe's ability to impose a severance tax on the contractor." 146 Accordingly, "[t]o accept the record in this case at face value, one must assume that the imposition of the tax had no effect upon the tribe's revenue, which simply seems implausible." 147 Professor Getches focused his attention on the Court's legal analysis, which he said "turned the Court's Indian preemption analysis on its head by starting with a presumption against the preemption of State law."148 Professor Clinton argued that the Court's application of the Indian Commerce Clause in Cotton Petroleum did violence to the framers' understanding of the Clause..$^{149}$

\section{c. Applying Bracker and Its Progeny to Water Marketing}

Even if one views Cotton Petroleum as controlling rather than aberrant authority, however, one need not conclude that it will determine the question of state regulation of interstate Indian water marketing. Both the preemption background of Indian water rights and the balance of the federal, tribal, and state interests involved are sufficiently different from those

144. See id. at 185-86.

145. See id. at 185 n.15.

146. Philip P. Frickey, Marshalling Past and Present: Colonialism, Constitutionalisn, and Interpretation in Federal Indian Law, 107 HARv. L. Rev. 381, 434 (1993).

147. Id. at 435 .

148. Getches, supra note 38, at 1619 n.202 (emphasis in original).

149. See Robert N. Clinton, The Dormant Indian Commerce Clanse, 27 CoNN. L. Rev. 1055, 1221-22 (1995). 
in Cotton Petroleum to suggest that Cabazon, Bracker, and, particularly, Mescalero, provide more parallel authority.

\section{i. Preemption}

Congress has never explicitly authorized or prohibited Indian water marketing as a general matter. ${ }^{150}$ But it has authorized the use of funds for lease of Indian water rights. In the 1985 Interior Appropriations Act, Congress provided that:

Hereafter tribal funds may be advanced to Indian tribes during each fiscal year for such purposes as may be designated by the governing body of the particular tribe involved and approved by the Secretary mcluding: . . . lease of lands and water rights . . . ${ }^{151}$

While this language does not discuss either the nature of the water right to be leased, the destination of the leased right, or the role of the states, it does make clear that congressional policy favors Indian water marketing.

Moreover, other sources do suggest congressional views of states' roles vis-à-vis water marketing. The first of these is the McCarran Amendment. ${ }^{152}$ As discussed above, while the Court has found that the McCarran Amendment authorizes state adjudication of Indian water rights in the context of a general adjudication, ${ }^{153}$ it has not recognized expansion of the McCarran Amendment's role beyond that point. Thus, the McCarran Amendment is significant not only for what it does say, but also for what it does not say; as the Court noted in McClanahan, "narrower statutes authorizing States to assert... jurisdiction over reservations in special situations are explicable only if Congress assumed that the States lacked the power ... without special authorization." 154

Other congressional enactments suggest even more directly that Congress did not intend for states to have control over Indian water rights.

150. It has, however, considered the issue in the context of various Indian water rights settlements. The results there have been mixed. In the Papago (now Tohono O'Odham Nation) Tribe's settlement, for instance, Congress explicitly provided for the Tribe to lease water. See Act of Oct. 12, 1982, Pub. L. No. 97-293, § 306(c)(2), 96 Stat. 1261, 1280. Similarly, the legislation confirming the Ak-Chin Tribe's settlement specifically authorized the Tribe to lease water to certain communities in Arizona, the state in which the Tribe is located. See Act of Oct. 24, 1992, Pub. L. No. 102-497, § 10(b), 106 Stat. 3255,3258 . But other settlements limited tribal abilities to market water by, for example, providing that tribal rights were to be treated as state rights if leased off-reservation. See Colorado Ute Indian Water Rights Settlement Act of 1988, Pub. L. No. 100-585, § 5, 102 Stat. 2973, 2974; Reclamation Projects Authorization and Adjustment Act of 1992, Pub. L. No. 102-575, § 503(c)-(d), 106 Stat. 4600, 4652-53 (Utah Ute Indian Water Rights Settlement). Because the politics of authorizing Indian water marketing in general are likely to be substantially different from the politics involved in discrete settlements, and because the results in existing settlements are mixed, these settlements do not seem an especially reliable source of authority for a court conducting a Bracker preemption analysis.

151. 25 U.S.C. $\$ 123 \mathrm{c}(1998)$.

152. 43 U.S.C. $\$ 666$ (1998).

153. See supra notes 21-25.

154. McClanahan v. Arizona State Tax Comm'n, 411 U.S. 164, 177 (1973). 
In Public Law 280, also at issue in Mescalero (but not Cotton Petroleum), Congress explicitly designated Indian water rights as a resource over which states were denied the civil jurisdiction which that Act afforded them more generally. ${ }^{155}$ This disallowance of state jurisdiction over water is essentially identical to the disallowance of state jurisdiction over wildlife that heavily influenced the Court's decision in Mescalero ${ }^{156}$-indeed, the disclaimers appear side by side in Public Law 280's treatment of criminal jurisdiction. ${ }^{157}$ Accordingly, it seems plausible to conclude, as did the Court in Mescalero, that "Congress would not have jealously protected tribal exemption from conflicting state ... laws had it thought that the States had residual power to impose such laws in any event."158

Similar intimations appeared in the Western Water Policy Review Act of $1992 .{ }^{159}$ There, Congress found that,

The Federal Government has recognized and continues to recognize the primary jurisdiction of the several states over the allocation, priority, and use of water resources of the States, except to the extent such jurisdiction has been preempted in whole or part by the Federal Government, including, but not linited to, express or implied Federal reserved water rights either for itself or for the benefit of Indian Tribes. . . . ${ }^{160}$

Clearly, then, Congress has not been agnostic in its view of State authority over Indian water rights. Instead, its pronouncements establish a fairly uniform view that States should not have control over Indian water rights. The only crack in this edifice is the McCarran Amendment. And, as noted above, in this sense it appears to be the exception that proves the rule. Consequently, to the degree that Congress has spoken to the issue of Indian water marketing, its pronouncements suggest preemption of state authority.

155. See 25 U.S.C. § 1322(b) (1998); 28 U.S.C. § 1360(b) (1998). The statute reads in relevant part:

(b) Nothing in this section shall authorize the alienation, encumbrance, or taxation of any real or personal property, including water rights, belonging to any Indian or any Indian tribe, band, or community that is held in trust by the United States or is subject to a restriction against alienation imposed by the United States; or shall authorize regulation of the use of such property in a manner inconsistent with any Federal treaty, agreement, or statute or with any regulation made pursuant thereto; or shall confer jurisdiction upon the State to adjudicate, in probate proceedings or otherwise, the ownership or right to possession of such property or any interest therein.

25 U.S.C. $\$ 1322$ (b); 28 U.S.C. $\$ 1360$ (b) (emphasis added). Virtually identical language appears in the codifications relating to criminal jurisdiction. See 18 U.S.C. § 1162(b) (1998); 25 U.S.C. § 1321(b) (1998).

156. See Mescalero, 462 U.S. at 340.

157. See 18 U.S.C. § 1162(b); 25 U.S.C. § 1321(b).

158. Mescalero, 462 U.S. at 340 n.25 (quoting McClanahan, 411 U.S. at 177) (internal punctuation omitted).

159. Pub. L. No. 103-437, 108 Stat. 4581 (codificd at 43 U.S.C. $\$ 371$ (1998)).

160. Id. § 3002(8). 
Some might argue, however, that Congress provided states with authority to regulate Indian water marketing when it approved the various interstate compacts discussed above. ${ }^{161}$ As noted in Part II(A)(1) of this Comment, states will likely rely on the "implicit authorization by compact" theory, regardless of whether the water right they seek to control is Indian or non-Indian.

Attributing to Congress an intent to abrogate tribal sovereignty when it ratified documents conceived before most people paid attention to Indian water rights at all, ${ }^{162}$ however, seems far-fetched. Indeed, because the Court required an express statement of congressional abrogation in the dormant Interstate Commerce Clause context in Sporhase, it follows a fortiori that it should require express congressional abrogation of Indian sovereignty pursuant to the Indian Commerce Clause. ${ }^{163}$ Existing case law suggests that the Court has in fact adopted such a view, at least in the context of state regulation of activities conducted by tribes themselves: "State laws generally are not applicable to tribal Indians on an Indian reservation except where Congress has expressly provided that State laws should apply." 164 Extending such a rule to a conflict where the burden of state regulation would so clearly fall on the tribe seems a short stretch.

Given the weighty array of express authority on the side of tribal sovereignty, and the utter absence of attention to Indian water rights in the various compacts, then, the compacts should not upset the preemption analysis discussed above.

\section{ii. "Particularized Inquiry" Test}

Some commentators have concluded, however, that in recent cases the Court has utilized the Bracker "particularized inquiry" test as no more than a naked balancing test, regardless of the preemption background. ${ }^{165}$ How might a court balance the interests at stake in an interstate Indian water marketing transaction?

As a preliminary matter, it is important to realize that any limitations a state might mipose on non-Indian purchasers of tribal water rights would indeed impact the tribe. If, for instance, a state sought to impose an outright regulatory ban on interstate Indian water marketing, and the only market for a tribe's water existed in downstream states, an outright ban would completely deprive a tribe of purchasers. Much the same would be true of a tax; even if the state did not impose a tax sufficiently high to deter purchasers altogether, the tax would diminish the market price of the

161. See supra text accompanying notes 53-64.

162. See sources cited supra at note 26.

163. See supra note 57 and accompanying text.

164. McClanahan v. Arizona State Tax Comm'n, 411 U.S. 164, 170 (1973) (citation omitted) (emphasis added).

165. See Canby, supra note 78 , at 22 ; Getches, supra note 38 , at $1619,1626$. 
tribe's water right. And even if some market for a tribe's water existed within state lines, eliminating or discouraging out-of-state demand for that water would depress the tribe's asking price. The following discussion assumes, therefore, that state barriers to interstate water marketing would indeed negatively impact the affected tribe.

Assessing state interests in imposing such barriers requires a minor amount of subtlety. At first glance, for instance, one might claim that the state should be entitled to conserve water-even Indian water-within its borders to protect existing users and safeguard compact apportionments. But if the state cannot prevent tribes from using their water on-reservation in the first place, the state has little legitimate interest in barring water marketing to prevent deprivation of existing uses. In other words, the state's interest should not be measured against non-use of Indian water; it should be measured against a tribe's full use of its entitlement on the reservation. When one works from this premise, it is clear that states cannot claim that existing users would be injured by a marketing transaction, since marketing would almost always result in less injury to existing users than would use on the reservation. ${ }^{166}$ Nor could states argue that revenue from use of the state's water should be conserved within the state, since, under McClanahan, on-reservation tribal economic uses of water would in most cases be immune from state taxation. Finally, since the purchaser is in another state, the exporting state can claim no interest in regulating contracts between tribes and its citizens.

These same objections undercut state arguments that rely on the sanctity of interstate compacts. Because compacts are not ends in themselves, but only instruments to assure state water security, they cannot supply to the states any legitimate interests in regulating Indian water rights that they lacked in the first place.

States could, however, likely point to some services they provide to tribes in the context of water administration. ${ }^{167}$ Most importantly, a state might argue that maimtenance of the roster of water rights and enforcing limits on appropriators benefits the tribe by ensuring that the tribe actually rcceives its water. While important, this interest does not seem sufficiently weighty to justify a state in preventing tribes from marketing their water. After all, a tribe could obtain similar safeguards through a federal court

166. The issue in this context would surround the quantity of water that the tribe sought to market. If the tribe sought to market its full reserved right, existing users might raise a challenge that had the water been used on-reservation, they would have benefited from return flow. If the tribe only sought to market a consumptive use, however, this problem disappears. Since average rcturn-flow rates for municipal and agricultural uses are widely available, calculating a consumptive use would pose little difficulty for a tribe. Consumptive use calculations would undercut any argument that a state might be able to "point to off-reservation effects that necessitate State intervention." Mescalero, 462 U.S. at 336.

167. See, e.g., supra text accompanying notes 137-42 (discussing Cotton Petroleum, 490 U.S. 163 (1989)). 
decree or injunction against offending appropriators; tribes need not rely on states to protect their water rights. And aside from administering water rights, states provide few, if any, services to tribes to enable them to develop their water. Traditionally, states have instead either obstructed or remained imdifferent to tribal water development. ${ }^{168}$

Opposed to state interests stand weighty tribal interests that do, arguably, go to a tribe's interest im self-government. For many tribes, water rights constitute an extremely valuable resource from which they could derive substantial, sustainable revenue by leasing on the open market. ${ }^{169}$ Indeed, since inany tribes cannot make use of their water resources on the reservations themselves, marketing provides a transitional activity that might enable tribes to raise funds sufficient to develop the facilities needed for on-reservation water use. Moreover, revenue from marketing would free tribes at least in part from reliance on federal appropriations and the attendant whims of the political process.

And to the degree that the value-added distinction established in Mescalero, Cabazon, and Colville survives Cotton Petroleum, it is clear that the tribal water resource falls well within the category of value derived from the reservation. As Winters made clear, tribal water rights are as much a part of the reservation as the land itself. ${ }^{170}$

Parallel to these tribal interests, of course, is the federal interest in Indian self-determination. As the Court noted in both Cabazon and Mescalero, federal statutes and executive policy have long elaborated the goal of greater tribal self-sufficiency. As noted im Cabazon, for instance, the Indian Financing Act of 1974 provided:

It is hereby declared to be the policy of Congress . . . to help develop and utilize Indian resources, both physical and human, to a point where the Indians will fully exercise responsibility for the utilization and management of their own resources and where they will enjoy a standard of living from their own productive efforts ..... ${ }^{171}$

Similarly, the Cabazon Court noted the President's 1983 Statement on Indian policy, which declared that "[i]t is important to the concept of self-government that tribes reduce their dependence on Federal funds by providing a greater percentage of the cost of their self-government."172

As cases like Mescalero, Cabazon, and Bracker indicate, a perhaps critical indication of federal interests is the presence of regulations and approvals issued by the Interior Department in support of the relevant

168. See supra note 26.

169. See supra text accompanying notes 1-4.

170. See supra text accompanying notes 44-45.

171. Cabazon, 480 U.S. at 216 n.19 (quoting 25 U.S.C. $§ 1451$ ) (emphasis added).

172. Id. at 217 n. 20 . 
tribal activities. While the Interior Department has not yet taken decisive action in this area, it does appear to be leaning in the direction of authorizing tribal marketing in general, and even interstate marketing in particular.

The most recent hint of the Department's views towards tribal marketing came in late September of 1998 . By simply publishing a notice seeking public comment in the Federal Register, ${ }^{173}$ the Department implied that it viewed tribal marketing of reserved water rights as at least a plausible option. Although the proposal at issue there did not involve marketing water across state lines, and although the notice was noticeably agnostic on the merits of tribal marketing, the very fact that it made it to the Federal Register is significant.

Perhaps the clearest indication that the Department might be favorably disposed towards interstate Indian water marketing came in a set of discussion draft regulations released for review by interested parties in 1994. ${ }^{174}$ There, the Bureau of Reclamation, a sub-agency within the Department, proposed a system that, inter alia, would have allowed interstate transfer of Indian reserved water rights among the states of the lower Colorado River basin. ${ }^{175}$ Owing perhaps to the substantial controversy that the Indian marketing provisions generated, ${ }^{176}$ the Bureau has not yet finalized this aspect of the regulations. ${ }^{177}$ But the 1994 draft regulations do at least indicate the present Department's inclinations on the issue. ${ }^{178}$

173. See 63 Fed. Reg. 51,367 (1998) (requesting comment on Chemehuevi Tribe's proposal to market water within the state of California). The Ak-Chin Tribe submitted a similar proposal in Arizona. See 61 Fed. Reg. 53,756 (1996) (announcing Ak-Chin Tribe's request to market water within the state of Arizona).

174. See Bureau of Reclamation, Draft Regulations for Administering Entitlements to Colorado River Water in the Lower Colorado River Basin (May 6, 1994) (on file with the California Law Review).

175. See id. at 8-19. The Department's primary concern was with the inherent limitations on marketability of Indian water rights, not with the external limits that States might seek to impose. See supra note 46 for a discussion of this distinction.

176. Chief opposition to the Indian marketing component of the discussion draft regulations came from the state of Arizona. See, e.g., Letter from Samuel P. Goddard, Jr., President, Central Arizona Water Conservation District, to Bruce E. Babbitt, Secretary of the Interior (July 18, 1994) (on file with the California Law Review). But Upper Basin interests also expressed concern in writing about this component of the regulations. See Letter from Wayne E. Cook, Executive Director, Upper Colorado River Commission, to Lawrence F. Hancock, Bureau of Reclamation (Jan. 27. 1995) (on file with the California Lav Review).

177. The Bureau released a proposed rule for public eomment on Deeember 31, 1997 that ineluded features of the discussion draft circulated in 1994. See 62 Fed. Reg. 68,492. Indian marketing was not among them.

178. The legal analysis in the regulations also suggests that the Department of the 1nterior may issue regulations explicitly preempting states from imposing barriers on interstate 1ndian water marketing. The Supreme Court has recognized administrative preemption in various cases. See generally LaURENCE H. TRIBE, American Constitutional Law $\$ 6-28$ (2d ed. 1987). In Hillsborough County v. Automated Med. Lab., Inc., for example, the Court noted that "the FDA possesses the authority to promulgate regulations pre-empting local legislation ... and can do so with relative ease." 417 U.S. 707, 721 (1985). And in Ray v. Atlantic Richfield Co., the Court held that state 
Whatever role the Department decides to play, the Supreme Court's jurisprudence in this area indicates that it will likely be a critical one. One issue on which the Department will not likely exercise substantial influence, however, is characterizing a water marketing transaction as occurring either on or off the reservation. In addition to the problem of state regulation of non-Indian purchasers, this is the other substantial category of difficulty facing interstate Indian water marketing transactions.

\section{The On-Reservation/Off-Reservation Distinction}

As noted above, it is well-settled that in the absence of explicit congressional authorization, states cannot directly tax or regulate the on-reservation, intra-tribal activities of Indian tribes or tribal members. ${ }^{179}$ States are, however, virtually unhindered in their regulation of tribal activities carried on outside of reservation boundaries. ${ }^{180}$ Much may turn,

regulation of tanker designs was foreclosed by Congress's grant to the Coast Guard of authority to inspect and license vessels. See 435 U.S. 151, 175-77 (1978).

Administrative preemption doctrine asks three questions to determine if an agency's regulation should have preemptive effect: (1) is the agency's intent to displace state law; (2) does the agency have the authority to speak in the general area involved; and (3) is the agency action in question a reasonable policy decision (not arbitrary or capricious)? See, e.g., Capital Cities Cable, Inc. v. Crisp, 467 U.S. 691, 699 (1984).

The second of these questions would likely be the most contentious here. But, as one commentator has noted in this context, because an agency's interpretation of its statutory mandate is due deference under Chevron U.S.A. Inc. v. Natural Resources Defense Council, 467 U.S. 837 (1984), a determination by the Secretary that he had the authority to promulgate regulations enabling interstate marketing of Indian water would possibly withstand challenge. See Paul E. McGreal, Some Rice With Your Chevron?: Presumption and Deference in Regulatory Preemption, 45 CASE W. REs. L. REv. 823, 824 (1995).

The Department set forth several sources of authority that might allow it to administratively preempt state barriers to marketing in the process of discussing why it thought it had authority to permit tribes to market their water despite the Non-Intercourse Act, 25 U.S.C. $\$ 177$ (1998). The Department focused on, inter alia, 25 U.S.C $\$ \$ 2,9$ and 415.

25 U.S.C $\$ \$ 2$ and 9 provide broad authority for the Department's supervision and management of Indian affairs, and partieularly for the protection of trust resources. "Courts have relied on $\$ \$ 2$ and 9 to uphold Secretarial authority to agree to sharing of water resources between Indians and non-Indians." Eric L. Garner \& Michelle Oulette, Future Shock? The Law of the Colorado River in the Twenty-First Century, 27 ARIz. ST. L.J. 469, 495 (1995) (citing United States v. Ahtanum Irrigation Dist., 236 F.20 321,336 (9th Cir. 1956)). 25 U.S.C $\$ 415$ is a general statute granting tribes broad authority to lease their lands with the approval of the Secretary of the Interior. 'The Department argues that the section should be construed liberally to promote tribal economic and governmental development and self-sufficiency. Furthermore, the Department has previously relied upon the section to provide consent for transactions involving the sale or lease of property rights independent from the land base itself. See Garner \& Oulette, supra, at 495. Conceivably, the Department might rely on these sources of authority to fashion preemptive regulations that would obviate the need for the Commerce Clause inquiry altogether.

179. See supra note 76

180. See Mescalero Apache Tribe v. Jones, 411 U.S. 145, 148-49 (1973). In a not-atypical example of the incoherence of the Court's Indian sovereignty doctrine, however, tribes remain immune from suit absent congressional authorization, regardless of whether the suit relates to actions taken onor off-reservation. See Kiowa Tribe v. Manufacturing Techs, Inc., 118 S. Ct. 1700, 1703 (1998) ("There is a difference between the right to demand compliance with state laws and the means available 
therefore, on a characterization of Indian water marketing transactions as occurring on- or off-reservation.

Mescalero Apache Tribe v. Jones ${ }^{181}$ most clearly exposes the onreservation/off-reservation dichotomy. In Jones, the Tribe operated a ski area on U.S. Forest Service land outside of reservation boundaries. New Mexico sought to impose its gross-receipts tax on the ski area, and the Tribe protested that its activities were immune from state taxation whether on- or off-reservation. The Court rejected the Tribe's assertion, noting that "[a]bsent express federal law to the contrary, Indians going beyond reservation boundaries have generally been held subject to nondiscriminatory state law otherwise applicable to all citizens of the State."182

\section{a. The Functional Interpretation of Jones}

Surprisingly, neither the Supreme Court nor the courts of appeal has fleshed out the underpinnings of the on-reservation/off-reservation distinction. Instead, courts simply cite to Jones for the proposition, and take its justification as self-evident. For cases involving stationary property, this is probably sufficient. But due to the fugitive nature of water as a species of property, at least for purposes of evaluating water marketing it is necessary to examine the analytic roots of the distinction.

In constructing the distinction, the Court in Jones relied on several cases that dealt, for the most part, with off-reservation fishing rights. ${ }^{183}$ These cases suggest that the Court may have used the on-reservation/offreservation distinction as an analytic shortcut for evaluating, $a$ la the Bracker particularized inquiry test, the various interests of the federal government, the state, and the tribe. ${ }^{184}$ That is, if a tribe is conducting activities off-reservation, it seems easier to conclude that its activities are not as essential to tribal self-government as are on-reservation activities. Similarly, it seems fair to conclude that the state's interests will be greater in off-reservation activities, since the state will have provided services (such as road maintenance and law enforcement) facilitating the conduct of the off-reservation enterprise.

Organized Village of Kake v. Egan, ${ }^{185}$ on which the Jones Court heavily relied, supports this reading. There, the Court cited Williams $v$. Lee $e^{186}$

to enforce them.”) Because states may thwart interstate Indian water marketing without bringing suit to enjoin a marketing transaction (for example, through authorizing private appropriation of the water to be marketed), tribal immunity from suit does not seem decisive here.

181. 411 U.S. 145 (1973).

182. Id. at $148-49$.

183. See, e.g., Puyallup Tribe v. Department of Game, 391 U.S. 392, 398 (1968); Organized

Village of Kake v. Egan, 369 U.S. 60, 75-76 (1962).

184. To be clear, all of these authorities, including Jones itself, preccded Bracker.

185. 369 U.S. 60 (1962).

186. 358 U.S. 217 (1959). 
for the proposition that "[t]he applicability of state law ... depends upon 'whether the state action infringed on the right of reservation Indians to make their own laws and be ruled by them.' ... [S]tate regulation of off-reservation fishing certainly does not impinge on treaty-protected reservation self-government ...."187

The Williams formulation also underlies the now-dominant Bracker "particularized inquiry" test. More miportant than doctrinal pedigree, however, is the fact that viewing the language in Jones as a proxy for the Bracker balancing test, rather than as a monolithic establishment of an on-reservation/off-reservation dichotomy, ${ }^{188}$ would bring some analytic consistency to cases involving disputes over tribal rights. If, after all, such issues turn on the relevant interests at stake for on-reservation disputes, why treat off-reservation disputes any differently? It would seem, in a word, inconsistent to apply balancing inside the reservation and a categorical rule outside.

Only such a harmonized approach would allow courts to fully grapple with the complex issues raised by interstate Indian water marketing. The fugitive nature of water as a species of property illustrates the difficulty of adopting a formalistic on-reservation/off-reservation reading of Jones. Water marketing does not easily lend itself to characterization as taking place on- or off-reservation. In an interstate marketing transaction, the tribal water right arises on the reservation, but it is wheeled through river systems and perhaps delivery works that are off-reservation, and the right is actually used off-reservation (indeed, not even in the state of origin).

The California Supreme Court may have recognized this problem in a somewhat parallel factual context. In People v. McCovey, ${ }^{189}$ the court held that California could not apply its law forbidding gill-net fishing against a tribal member seeking to sell fish validly gillnetted on the reservation. To be sure, the court in McCovey did not explore the rationale underlying the on-reservation/off-reservation distinction as I have above. But despite the fact that the tribal member there sought to sell fish off-reservation, the court distinguished Jones and instead applied Bracker. In distinguishing Jones, the court noted that "the Indian activity in [Jones] occurred entirely off the reservation, while this case involves on-reservation fishing followed by an off-reservation sale." 190

187. Organized Village of Kake, 369 U.S. at $74-76$ (quoting Williams, 358 U.S. at 220).

188. Such a reading derives at least some support from the Court's use of the word "generally" in Jones. See supra text accompanyiug note 182.

189. 685 P.2d 687 (Cal. 1984).

190. Id. at 697. The court also declined to apply the northwest fishing cases which had granted to states relatively broad authority to regulate fishing. See supra note 117 . The court found these cases inapposite for several reasons: First, they pre-dated Bracker; second, they involved no "comprehensive federal regulatory scheme" as existed in McCovey; and third, the facts of McCovey indicated that the state did not have a "reasonable and necessary" purpose for regulating on the basis of conservation. See McCovey, 685 P.2d at 696. 
If a court were willing to accept the functional characterization of Jones sketched above and perhaps implicitly adopted in McCovey, it would essentially evaluate the marketing transaction under Bracker. Accordingly, as elaborated above, the interests at stake would likely tilt in favor of tribal inarketing, and any state restraints on interstate tribal marketing would fall. ${ }^{191}$

\section{b. The Formalistic Interpretation of Jones}

Because only the functional approach to Jones sketched above fully confronts the issues attending interstate Indian water marketing, this Comment advocates adopting that approach. If a court instead insisted on a wooden, formalistic reading of Jones, however, proponents of marketing might advance alternative theories in an attempt to characterize a marketing transaction as an exclusively on-reservation activity. One way of attempting this, for exainple, would be to specify the reservation in a forum-selection clause in a contract.

Courts in the Ninth Circuit have recognized that ordinary contract law principles may operate to designate the reservation as the situs of a transaction. ${ }^{192}$ And at least one court has applied this analysis in tandem with Jones by noting that "if the [c]ourt were to find that the activities giving rise to the dispute in this case took place off the reservation, then it is likely the state court would have jurisdiction over the underlying action." 193

Such analyses, however, would short-shrift the issues at stake in an evaluation of interstate Indian water marketing transactions, and would not provide a court with any more-easily-applicable standards. The contractsitus test applied by the Ninth Circuit, for instance, places great emphasis on the physical location of the "chattel" at issue..$^{194}$ Because of water's fugitive character, however, in a water marketing question this would essentially re-establish the problem inherent in the formalistic reading of Jones. Even if a court were to read Jones formalistically, therefore, it would likely be forced to confront the same difficulties of how to site marketed water. The difference, however, is that run-of-the-mill contract analysis does not take account of the serious tribal interests at stake in an Indian water marketing transaction. Issues going to the very heart of tribal sovereignty should not be resolved in the same way as routine contract disputes.

Despite all of the preceding considerations attending a rigid reading of the on-reservation/off-reservation distinction, it is of course quite

191. See supra text accompanying notes 163-74.

192. See R.J. Williams Co. v. Fort Belknap Hous. Auth., 719 F.2d 979 (9th Cir. 1983). The court in R.J. Williams applied a five-factor test derived from the Restatement (Second) of Conflict of Laws. See id. at 985 (citing Restatement (SECOND) OF Conflict of LAws $\$ 188(2)$ (1971)).

193. Tohono O'Odham Nation v. Schwartz, 837 F. Supp. 1024, 1032 (D. Ariz. 1993).

194. See R.J. Williams, 719 F.2d at 985. 
possible that a court might insist on characterizing tribal marketing as an off-reservation phenomenon, and insist on applying Jones in a formalistic manner. If it were to do so, tribes' only recourse would likely be the administrative preemption alluded to above ${ }^{195}$ or an act of Congress. It is my sense, however, that a more a principled and informative approach to the issue requires adopting the functionalistic reading of Jones discussed above.

\section{Summary}

To summarize, because states are generally forbidden from interfering directly with tribes engaged in on-reservation activity, states wishing to inhibit interstate Indian water marketing would likely attempt either to regulate the non-Indian parties to a transaction, to characterize a marketing transaction as taking place off-reservation, or both.

In analyzing state attempts to regulate non-Indian parties, both the Bracker preemption and "particularized inquiry" tests would tilt in favor of the tribes and their purchasers.

The on-reservation/off-reservation distinction seems a weaker spot for the tribes; to date, no court has adopted the functional approach advocated herein. But there may be a good reason for the dearth of analysis on this point; courts have rarely grappled with issues like water marketing that actually raise the question of what underlies the distmction. If not an outright sui generis form of property, water's fugitive character makes finding firm parallels difficult. Because the functional interpretation of Jones advocated above promises more consistency than does a formalistic reading, this Comment opts for an optimistic view of tribes' chances in the realm of the on-reservation/off-reservation distinction.

\section{CONCLUSION}

Tribes face numerous obstacles in their attempts to market their water across state lines. This Comment addresses only one of those obstacles: barriers imposed by state law. Due to their distinctive status as quasisovereign entities, however, it seems likely that tribes will be immune from state barriers that might otherwise apply. To be sure, the mere existence of a state barrier poses a substantial burden on a tribe: The costs involved in challenging such barriers may themselves make interstate marketing transactions uneconomical. But this Comment does suggest that if a tribe were to challenge such a barrier, it should stand a good chance of success. In the interim, perhaps the most valuable thing tribes can do to increase their chances of prevailing should such disputes arise is to work with the Interior Department to secure departmental approval and endorsement of their

195. See supra note 178 . 
marketing plans. Even if such involvement does not rise to the level of a departmental regulation explicitly preempting state law, it will likely have a substantial impact on the analysis. 